\title{
Effectiveness of VAR (Virtual Augmented Reality)- Based Educational Games in Trigonometry Learning in University
}

\author{
Noviana Dini Rahmawati ${ }^{1}$, Achmad Buchori ${ }^{2}$, Arif Wibisono ${ }^{3}$ \\ ${ }^{1}$ Universitas PGRI Semarang, Central Java, Indonesia \\ ${ }^{2}$ Universitas PGRI Semarang, Central Java, Indonesia \\ ${ }^{3}$ Universitas PGRI Semarang, Central Java, Indonesia \\ *Corresponding author.Email: novianadini@upgris.ac.id
}

\begin{abstract}
The development of technology today is very demanding of a teacher to be able to develop effective media in the learning process. Trigonometry learning is one of the courses in higher education that requires a virtual understanding of concepts. Therefore, it is very important to have fun virtual media through games in understanding the concept of Trigonometry. The purpose of this study was to determine the effectiveness of educational games based on VAR (Virtual Augmented Reality) in learning trigonometry in university. The research method uses the ADDIE model (Analysis, Design, Development, Implementation, Evaluation). However, this article contains the implementation stages. The data analysis techniques of this research are the Normality Test, Homogeneity Test, T-test. From the results of the study, it can be concluded that learning trigonometry using educational games based on Virtual Augmented Reality meets the effective criteria because the experimental class learning outcomes are better than the control class and the results of the student response questionnaire to the VAR-based educational game media showed that the media was very effective in learning trigonometry in university.
\end{abstract}

Keywords: educational games, virtual augmented reality, trigonometry

\section{INTRODUCTION}

Trigonometry is a mathematical science that is considered difficult by students and is abstract compared to other mathematical sciences. Some people do research related to trigonometry. [1] stated that the mistakes that many students make in studying trigonometry are the use of inappropriate equations, order of operations, and sine values. Cosine, data misuse, language meaning error, invalid logical inference mechanical error. In research [2] students learn about trigonometric connections including definitions of sine and cosine. The results show that many students have a fragmented understanding of the three main ways of viewing sine and cosine as coordinates of points on a circle, as horizontal and vertical distances which are the graphical requirements of these coordinates, and as side comparisons of triangles. According to [3], teacher teaching qualifications do not correlate with students' academic achievement in learning trigonometry. An educator needs to encourage students' interest in learning trigonometry and teachers need to acquire pedagogical knowledge and be able to apply innovative learning media in teaching trigonometry.

Learning media has an important role in facilitating teachers in conveying a concept. Research that has been done by [4], trying to apply learning media in the form of educational games shows that games have a good effect and have an effect on increasing student achievement and creating interactive environment. Educational game design and game-based learning approaches have been developed gradually across various disciplines. Gamebased learning really provides more utilization to guide students to learn about certain concepts according to disciplines [5].

Understanding a concept requires innovative and interactive media with students. Through the combination of AR technology with educational content has created a new application that serves to increase the attractiveness of teaching and learning activities in real life. Augmented Reality is a new medium that combines 
aspects of ubiquitous computing, real computing, and social computing. This media unites the virtual and real worlds [6]. According to research conducted by [7], the application of VR can be used to introduce children to seeing the stars and the application of AR technology is able to create a solar system at the student desk. So that students can interact in science learning. Thus, both AR and VR technology have shown that both can be used effectively for teach information about science. However, AR and VR have advantages and disadvantages so it is necessary to adjust the technology integration with the learning environment. Both technologies are able to provide new innovations in the interesting world of education.

Trigonometry learning at UNIMUS Semarang still uses media in the form of textbooks and has not implemented a technology-based media. In fact, students need to understand the concept of trigonometry visually through interesting and fun media. Therefore, the author wants to know the effectiveness of VAR-based educational games on trigonometry learning at university.

\section{RESEARCH METHODS}

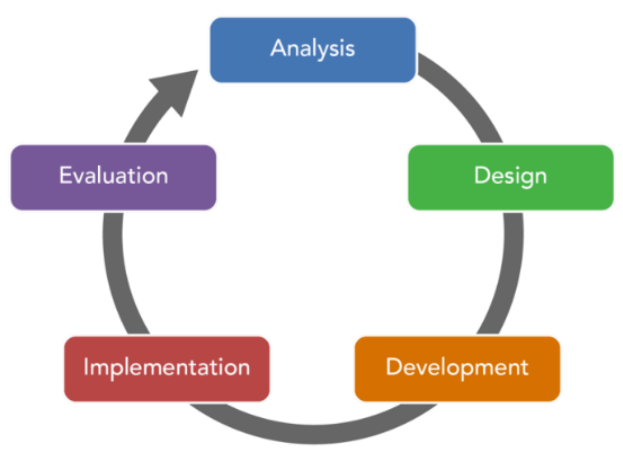

Figure 1. ADDIE model

This type of research is research and development. This research method is the method used to produce educational game products based on Virtual Augmented Reality (VAR) in Trigonometry learning at the University. The population of this research is the first semester students of UNIMUS mathematics education study program. The software used in the development of this media is the Unity 3D software, Blender, Vuforia Development and Corel Draw. The data collection technique used is the method of documentation, tests, and student response questionnaire. The data analysis techniques of this research are the Distribution Normality Test, Homogeneity Test, and t-test. The development procedure in this study is the ADDIE model which includes (1) analysis, (2) design, (3) development, (4) implementation, (5) evaluation. The ADDIE model is a cycle design model that has several advantages, including being flexible enough to allow anyone and at any time to review a step and refine it [8]. The procedure can be seen in Figure 1. However, this article contains the implementation stages.

\section{RESULTS AND DISCUSSION}

The application of the expanded product test was carried out at UNIMUS Semarang by taking samples of 1 st semester students, class $1 \mathrm{~A}$ as the experimental class and class $1 \mathrm{C}$ as the control class. Because the research was carried out during the Covid-19 pandemic, the expanded trial was carried out online using the Zoom platform. Lecturer response questionnaires and student responses using Google Forms. Post-test data analysis was conducted to determine whether the experimental class and control class had differences between conventional learning and learning using VAR-based educational games in trigonometry learning. Furthermore, the researchers analyzed the post-test data that had been carried out in class $1 \mathrm{~A}$ and class $1 \mathrm{C}$. The steps used to analyze the post test data are as follows.

\subsection{Normality test}

To Calculation of the initial data normality test with a significant level of 5\% using Liliefors. Hypothesis test on the calculation of the normality of the initial data are as follows: Ho : $L_{0}<L_{\text {tabel }}$ then the population is normally distributed. Ha : $L_{0}>L_{\text {tabel }}$ then the population is not normally distributed. The following results were obtained.

Table 1. Normality Test

\begin{tabular}{|l|c|c|c|l|}
\hline Class & $\mathrm{n}$ & $L_{0}$ & $L_{\text {tabel }}$ & Decision \\
\hline $\begin{array}{l}\text { Experiment } \\
(1 \mathrm{~A})\end{array}$ & 25 & 0,115 & 0,173 & $\begin{array}{l}\text { Normal } \\
\text { distribution }\end{array}$ \\
\hline Control (1C) & 22 & 0,137 & 0,184 & $\begin{array}{l}\text { Normal } \\
\text { distribution }\end{array}$ \\
\hline
\end{tabular}

From the table it is clear that $0.115<0.173$ and 0.137 $<0.184$. So with a significant level of $5 \%, L_{0}<L_{\text {tabel }}$ on control class and experimental class with $n_{1}=25$ and $n_{2}=22$ so Ho is accepted. This means that the samples from the experimental class and the control class samples come from samples that are normally distributed.

\subsection{Homogeneity Test}

Homogeneity test is used to test the similarity of two variances. From calculation with MS. Excel obtained $F_{\text {count }}=1,57$, with alpha $=0.05$ and $\mathrm{dk}$ the numerator $(25$ - $1=24)$, dk the denominator $(22-1=21)$, so $F_{(0,05)(24,21)}=2,57$. Ho acceptance test criteria if $F_{\text {count }}<F_{\text {table }}$. Because $F_{\text {count }}<F_{\text {table }}$ is $1.57<2.57$ then Ho is accepted, so it can be concluded that the variance between groups is homogeneous (same).

\section{3. $T$-test}

The effectiveness of Virtual Augmented Reality (VAR) based Educational Game media is tested by using 
an experimental design that is Post test Only Control Design. In design There are two groups, namely the experimental group and the control group. Design This experiment is used to compare student achievement between groups experimental group and control group in the hope that the experimental group's performance will be better than the control group. The hypotheses used in this study are as follows.

Ho $=$ The results of learning mathematics using Virtual-based Educational Game media Augmented Reality (VAR)) there is no difference with the learning model conventional.

$\mathrm{Ha}=$ Mathematics learning outcomes using Virtualbased Educational Game media Augmented Reality (VAR) is better than the learning model conventional.

To find out which learning is better, the t-test test is used (the right).

\begin{tabular}{|l|l|l|l|l|}
\hline Class name & $\begin{array}{l}\text { Mean } \\
\left(\bar{X}_{l}\right)\end{array}$ & $n_{i}$ & $t_{\text {count }}$ & $t_{\text {table }}$ \\
\hline $\begin{array}{l}\text { The } \\
\text { experimental } \\
\text { class }\left(X_{1}\right)\end{array}$ & 88.57 & 25 & 4,69 & 1.78 \\
\cline { 1 - 3 } $\begin{array}{l}\text { The control } \\
\text { class }\left(X_{2}\right)\end{array}$ & 69.84 & 22 & & \\
\hline
\end{tabular}

Based on calculations with MS. Excel obtained the average of the experimental class namely $x_{1}=88.57$ and the control class average is $x_{2}=69.84$ with $n_{1}=25, n_{2}$ $=22$ and $\mathrm{s}=15,503$ so that $t_{\text {count }}=4,69$ is obtained. The result of $t_{\text {count }}$ is compared with $t_{\text {table }}$. From distribution list $\mathrm{t}$ with probability 0.95 and $\mathrm{dk}=25$ then $t_{0,95}$ is 1.78. From calculation obtained $t_{\text {count }}$ of 4.69 and $t_{\text {table }}$ of 1.78 . Because $t_{\text {count }}>t_{\text {table }}$ that is $4.69>$ 1.78 then Ho is rejected.

Based on the above calculations because Ho is rejected, it can be concluded that the learning outcomes mathematics using Virtual Augmented Reality (VAR)based Educational Game media better than conventional learning models. This proves there is differences in learning achievement because lecturers use two different treatments between classes control and experimental class with the average value of the experimental class, namely $x_{1}=88.57$ and the average control class that is $x_{2}=69.84$.

This is supported by research conducted by [9], which concludes that the emergence of virtual technology capable of supporting augmented reality has provided tremendous opportunities for improve the way we learn. The use of this media can increase student involvement in interaction with the surrounding environment, both inside and outside the building. Advances in pedagogical development Virtual or augmented concepts, applications and technologies are appropriate for educational institutions. However, the potential of both $\mathrm{VR}$ and $\mathrm{AR}$ requires careful reflection to be true translated into educational efficacy. Thus, it is hoped that the use of this technology can provide benefits in improving student achievement [10].

\subsection{Student Response Results}

Data collection on student responses to learning media based on Virtual Augmented Reality (VAR) was obtained through a google form link questionnaire. Questionnaire links were given to students after students finished using Virtual Augmented Reality (VAR)-based Educational Game Media. This aims to find out how well the Virtual Augmented Reality (VAR)-based Educational Game media is used for students. From the calculation results, the average percentage of students is $90.64 \%$. After conversion with a scale conversion table, the Virtual Augmented Reality (VAR)-based Educational Game media is in the range of $81 \%-100 \%$. So getting the criteria is very good. The percentage score of each student response criteria can also be seen in the form of a chart in Figure 2.

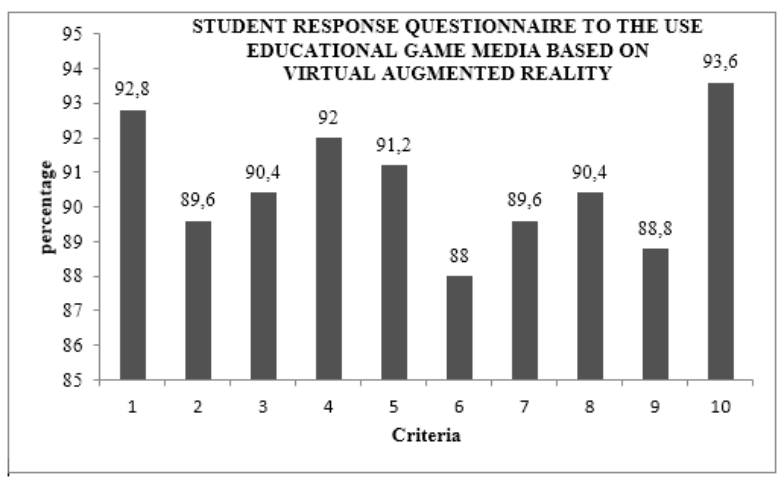

Figure 2 Bar Graph of Student Response Questionnaires

\section{CONCLUSION}

From the results of the study, it can be concluded that learning trigonometry using educational games based on Virtual Augmented Reality meets the effective criteria because the experimental class learning outcomes are better than the control class as indicated by the value $t_{\text {count }}=4,69>t_{\text {table }}=1,78$ and the experimental class has an average 88.57 and the control class has an average of 69.84 . In addition, the student response questionnaire to the VAR-based educational game media showed $90.64 \%$ which indicated that the media was very effective in learning trigonometry at university. 


\section{REFERENCES}

[1] Gur, H. (2009). Trigonometry Learning. New Horizons in Education, 57(1), 67-80.

[2] Brown, S. A. (2006, July). The trigonometric connection: students' understanding of sine and cosine. In Proceedings 30th Conference of the International Group for the Psychology of Mathematics Education (Vol. 1, p. 228).

[3] Sumaila, M. U. (2020). Teachers Teaching Qualifications as Predictors of Performance in Trigonometry among Secondary School Students in Kano Metropolis, Nigeria. ATBU Journal of Science, Technology and Education, 8(1), 296-301.

[4] Mubaslat, M. M. (2012). The Effect of Using Educational Games on the Students' Achievement in English Language for the Primary Stage. Online Submission.

[5] De Freitas, S. (2018). Are games effective learning tools? A review of educational games. Journal of Educational Technology \& Society, 21(2), 74-84.

[6] Kesim, M., \& Ozarslan, Y. (2012). Augmented reality in education: current technologies and the potential for education. Procedia-social and behavioral sciences, 47, 297-302.

[7] Huang, K. T., Ball, C., Francis, J., Ratan, R., Boumis, J., \& Fordham, J. (2019). Augmented versus virtual reality in education: an exploratory study examining science knowledge retention when using augmented reality/virtual reality mobile applications. Cyberpsychology, Behavior, and Social Networking, 22(2), 105-110.

[8] Davis, A. L. (2013). Using instructional design principles to develop effective information literacy instruction: The ADDIE model. College \& Research Libraries News, 74(4), 205-207.

[9] Boyles, B. (2017). Virtual reality and augmented reality in education. Center For Teaching Excellence, United States Military Academy, West Point, Ny.

[10] Kaufmann, H. (2003). Collaborative augmented reality in education. Institute of Software Technology and Interactive Systems, Vienna University of Technology. 